\title{
Assessment of attitudes towards the use of topical corticosteroids among patients, prescribers and pharmacists in the Republic of Macedonia
}

\author{
Marija Glavas-Dodov ${ }^{1 *}$, Maja Simonoska-Crcarevska ${ }^{1}$, Vanja Sulevski ${ }^{1}$, \\ Renata Slaveska Raicki ${ }^{1}$, Agron Starova ${ }^{2}$ \\ ${ }^{1}$ Institute of Pharmaceutical Technology, Faculty of Pharmacy, University "Ss Cyril and Methodius", \\ Majka Tereza 47, 1000 Skopje, Macedonia \\ ${ }^{2}$ University Clinic of Dermatology, Majka Tereza 17, 1000 Skopje, Macedonia
}

Received: January 2016; Accepted: March 2016

\begin{abstract}
Apart from the time-proven, gold standard treatment of many topical conditions with corticosteroids, the phobia of using topical corticosteroids (TCs) is a phenomenon unveiled among groups of patients, parents, as well as health professionals. Health professionals' attitude to TCs could have a significant impact on the trend of TCs-phobia among patients. Therefore, it is essential to address this issue as TCs-phobia is something which could also have important implications in medication adherence and compliance to prescribed treatment.

Bearing in mind that no survey had been conducted to investigate this matter in Republic of Macedonia (RM), a self-completed questionnaire has been created to assess attitudes and their prevalence associated with TCs-phobia among patients and health professionals with aim to describe the attitude, explore the reasons behind revealed phenomenon and define directions for future interventions needed to advance the healthcare in this field.

Our findings show that the TCs-phobia is present among surveyed population (21.6 and $34.22 \%$ of all responders expressed negative attitudes or fear of TCs use, respectively). It is also concluded that $\sim 27 \%$ of patients on TCs-therapy admitted that they feared of using the medication. However, there is a higher frequency of negative attitudes regarding the use of TCs among the health professionals $(\sim 39 \%)$ than among patients, where the TCs-phobia is more prominent among non-dermatologists than dermatologists. Moreover, negative attitude and fear of TCs use is universal among paediatricians (73.91\%).

Portrayed interventions needed to identify and manage the TCs-phobia can lead to improvement of adherence and predicted responsiveness of TCs-therapy.
\end{abstract}

Keywords: topical corticosteroids, corticophobia, survey

\section{Introduction}

For more than six decades, topical corticosteroids (TCs) have been proven to create a main stay of medical treatment for many dermatologic conditions due to their anti-inflammatory, vasoconstrictive and immunomodulatory effects (Balkrishnan et al., 2005; Cornell and Stough- ton, 1985; Ference and Last, 2009; Haber, 2010; Katz et al., 1987; Miller and Munro, 1980; Roos et al., 2004; Tadicherla et al., 2009).

Since the synthesis of hydrocortisone in 1951 to present, an increasing number of TCs pharmaceuticals available in various topical dosage forms (e.g. solutions, lotions, creams, ointments, gels, sprays and mousses) with different strengths are placed on the global market. A com-

*magl@ff.ukim.edu.mk 
mon rule is to use ointments on dry skin and creams on wet areas. Furthermore, several high-potency TCs are available with salicylic acid or combined with other drug substances (for example, antibiotics or antifungals) (Alston et al., 2003). However, in continuum, the greatest challenge for the scientists is the development of more potent corticosteroid drug molecules with reduced risks of side-effects (Hengge et al., 2006; Leung and Barber, 2003; Mason et al., 2002). As acknowledged, TCs can be classified according to their potency and pharmaceutical vehicles. TCs may differ in potency based on the vehicle or concentration which affects their absorption and efficacy. The potency is determined by the amount of vasoconstriction a TC produces and the degree to which it suppress the inflammatory pathways (Jacob and Steele, 2006). Nevertheless, similar vasoconstricting ability does not indicate therapeutic equivalence (Kanfer, 2010; Menter et al., 2008). According to the present systems of TCs potency, it is obvious that classification can vary depending on the source (NPF, http://www.resourceclinical.com). In general, TCs are classified into four groups by potency - mild, moderate, potent and very potent. Thus, the World Health Organization Classification of TCs also includes four classes consisting of seven groups in total (Ultra High Potency Class with Group 1, High Potency Class with Group II and III, Moderate Potency Class with Group IV and Low Potency Class with Group VI and VII) (Bolognia et al., 2012), whereas the USA classification of TCs is based upon the potency and ranges from Class 1 (the ultra-high) to Class 7 (the least potent). It is important to note that classifications are based on a finished pharmaceutical product, and not only on a specific corticosteroid molecule.

In considering prescriber's opinion, it is recommended that the lowest potency TCs should be used as first line treatment option to control the skin condition. Nevertheless, it is appropriate to use a very high potent TC for a short period of time because of the potential for systemic side effects (Menter et al., 2009; National Guideline). However, for successful TC treatment and therapy outcomes, two aspects have to be considered: the first is related to the decision-making process and prescribing pattern for TCs of choice and the second is focused on the patient adherence and compliance with the prescribed TC therapy. In more details, influential factors include: patient's age, type of skin condition or lesion of the affected area, clinical presentation and severity of condition, accurate diagnosis, choice of optimal dosage, the anatomical site of application, frequency of administration, duration of treatment and side effects (Lee and Marks, 1998; Pariser, 1991). In addition, the potential for irritation or allergy also influences the selection of TC (Haeck et al., 2009; Torres and Canto, 2010).

Without any concerns, the efficacy and safety of TC treatment have been clearly established and confirmed. Thus, numerous studies, clinical practices and guidelines have shown that these medicinal molecules still remain to be the first-line and/or the gold standard for treatment of chronic relapsing skin conditions such as atopic and contact dermatitis, eczema, psoriasis, lichen etc., when patients used them appropriately, according to the regime and advice given by healthcare professionals (doctors and pharmacists) (Ashcroft et al., 2000; Bewley, 2008; Drake et al., 1996; Renaud-Vilmer et al., 2004; Saeki et al., 2009).

TCs are safe and effective if used appropriately. Patient's adherence to the therapy is another significant factor for their success. Therefore, as mentioned above, the quality patient education and support about the appropriate use of TCs are crucial for the compliance, with a special focus on TCs when used as part of a complex treatment regimen. Despite the long history of TCs effectiveness, the best practices for choosing TC to safely and effectively treat patients conditions and the great progress accomplished in TC pharmaceuticals, the use of TCs is still largely constrained by the emotional concerns (usually called ' $\mathrm{TC}$ phobia') present in a substantial number of patients, parents and healthcare professionals. Furthermore, the significant number of studies has confirmed that patients poor or non-adherence to TC treatment is correlated to TC phobia (Charman et al., 2000). These fears, beliefs and attitudes, whether or not rational, could be the main cause of the poor or non-adherence to TCs therapy. Underuse of TCs can consequently reduce the treatment response in many patients, which later on can also lead to increased health care costs. In general, TCs phobia is a frequent concern expressed by $40 \%$ to $73 \%$ of dermatology patients (Smith et al., 2013a). However, designating the fear associated with TCs use as "phobia" may well be a misnomer because of the number of rational reasons behind patients' fear of TCs (Smith et al., 2013b). As a consequence, patients not only are often advised and warned of the risk of TCs by friends, relatives and even by various media, but also by traditionally trusted sources such as health care providers, doctors and pharmacists. This situation very often creates an unenthusiastic cultural environment for patients and may lead to poor or nonadherence to prescribed TC treatment. Generally speaking, reports of treatment non-adherence and negligence are in the range of $20-80 \%$ (Aubert and Barbarot, 2012). On one hand, poor adherence to medicine treatment in most cases is associated with long-term regimens, asymptomatic disease conditions, regimen complexity, life style, misperceptions, etc., and on the other hand, good adherence is associated with more severe symptoms of disease, knowledge about and efficacy of the treatment, adequate social support and trust in the doctors and pharmacists (Aubert and Barbarot, 2012).

In an era where efficacious drug therapies exist or are being developed at a rapid rate, it is discouraging that one half of patients whom appropriate medication is prescribed fail to utilize the full medicine benefits because of inadequate adherence and compliance to prescribed treatment caused by different reasons, beliefs or misperceptions. 
Table 1. The most frequently dispensed prescription TCs in the Republic of Macedonia*

\begin{tabular}{|c|c|c|}
\hline $\begin{array}{l}\text { Generic drug product } \\
\text { (ATC code D07) }\end{array}$ & $\begin{array}{l}\text { Classification of TC } \\
\text { Potency } \\
\text { (Class/Group) }\end{array}$ & $\begin{array}{l}\text { Number of dispensed prescrip- } \\
\text { tion TCs (drug packages) }\end{array}$ \\
\hline Betamethasone dipropionate $(0.05 \%)$ (ointment/cream) & $\begin{array}{l}\text { Group II/III,WHO } \\
\text { Potent, Class II/III UK }\end{array}$ & 102938 \\
\hline $\begin{array}{l}\text { Betamethasone dipropionate }(0.05 \%) \text { and salicylic acid } \\
\text { (ointment/lotion) }\end{array}$ & $\begin{array}{l}\text { Group II and VWHO } \\
\text { Potent, Class II/III UK }\end{array}$ & 49623 \\
\hline Diflucortolone valerate $(0.1 \%)$ (cream/ointment) & Potent, Class II UK & 79558 \\
\hline $\begin{array}{l}\text { Methylprednisolone aceponate }(0.1 \%) \text { (cream/emulsion/ } \\
\text { ointment) }\end{array}$ & $\begin{array}{l}\text { Group VII WHO } \\
\text { Moderate potency, Class III,UK }\end{array}$ & 31946 \\
\hline $\begin{array}{l}\text { Hydrocortisone or hydrocortisone acetate }(0.5,1 \text { and } 2.5 \%) \\
\text { (cream/ointment/spray) }\end{array}$ & $\begin{array}{l}\text { Group VII WHO } \\
\text { Mild potency, Class IV UK }\end{array}$ & 253 \\
\hline
\end{tabular}

* Ministry of Health of the R. Macedonia, Annual report, June 2014.

The prescription TC medicines available in the $\mathrm{R}$. Macedonia, their relative potencies, as well as their annual dispensing according to the prescribing practice are presented in Table 1 (June 2013 - June 2014).

As presented in Table 1, it is obviously that the most frequently dispensed prescribed TCs belong to the potent group while, the dispensing of a moderate and mild TCs is less prevalent. These data were intriguing to explore the adherence to TC prescribed treatment since to the best of our knowledge, no comprehensive study assessing factors associated with adherence to treatment advice on TCs including nature, origins and frequency of TC phobia (if present) among patients and caregivers, has been conducted to present in our country.

Therefore, the aim of the present assessment was to obtain information on the frequency of TC use among patients in the RM and to evaluate the origins and emotional attitudes towards the use of TCs in patients and healthcare professionals, as well as reasons behind the eventual lack of adherence to treatment recommendations (Bewley, 2008).

\section{Materials and methods}

\section{Questionnaire-structuring process}

Bearing in mind that it has always been considered a good survey practice to pre-test and to ensure that questions can be easily understood and answered by respondents, during the first step of the questionnaire-structuring process a focus group methodology was applied. Actually, this phase was conducted in the course of June and August 2013 and involved 16 adult patients with dermatological problems and 16 health professionals ( 8 general practitioners and 8 community pharmacists) in order to collect preliminary data on real-life attitudes, beliefs and perceptions about TC treatment and phobia. As mentioned above, this screening questionnaire was also developed with the aim to explore the level of understanding, acceptability (ques- tions wording, complexity and ambiguity of proposed answers), the time required to complete the questionnaire. Obtained results enabled us to generate direct anonymous final questionnaire consisting of 25 refined items. Faculty of Pharmacy, "Ss Cyril and Methodius University" in Skopje, RM, approved this questionnaire and study.

\section{Study design and data collection}

An anonymous self-completed questionnaire specifically designed for the purpose of the current study involved four main groups of questions covering: (1) demographic and socio-economic characteristics, (2) basic knowledge about corticosteroid therapy, (3) attitudes, beliefs and perceptions about TC treatment and phobia (if present); and (4) degree of confidence and trust of patients in health-care professionals and confidence and trust among health-care professionals. The enclosed cover letter served as informed consent for the questionnaire.

Demographic and socio-economic characteristics of the respondents were considered as independent variables - X (in total 7 items). Moreover, the questions related to TC treatment and the source and prevalence of TCs phobia were considered as dependent variables - Y (in total 18 items). The qualitative data were collected between October 2013 and April 2014 from different regions of the RM. Strictly speaking, precisely 400 questionnaires were distributed in all regions of the RM and 360 filled in were returned back ( $90 \%$ response rate). Items with a rate of missing values $>20 \%$ were eliminated and, thus, 301 questionnaires were finally included in the analysis.

Key respondents were selected from a pool of patients who attended a doctor's appointment (examination) (specialist or general practitioner) or visited the community pharmacy. They were asked to complete the questionnaire prior the consultation with health professionals. This was also followed by a representative questionnaire survey among doctors (general practitioners, dermatologists, paediatricians) and pharmacists in their professional envi- 
ronment.

Obtained data were tabulated using Microsoft Excel ${ }^{\circledR}$ (Microsoft Corp. Redmond, WA, USA) and were computed and consequently evaluated using statistical software STATGRAPHICS Centurion XVI evaluation (StatPoint technologies Inc., USA) and multivariate statistical analysis software SIMCA 13 (Unimetrics AB, Sweden). Values of $p$ less than 0.05 were considered significant.

\section{Results and discussion}

\section{Characteristics of the population samples}

The study included a nationally representative sample of 301 adults aged 16 and older. Mean age \pm Standard Deviation (SD) of the respondents was $40.87 \pm 15.1$ years. Detailed socio-demographic characteristics of the interviewed sample are presented in Table 2.

In order to study the TCs use and to determine the reasons for patients' adherence/non-adherence to prescribed

Table 2. Detailed socio-demographic characteristics of the surveyed population groups $(\mathrm{n}=301)$

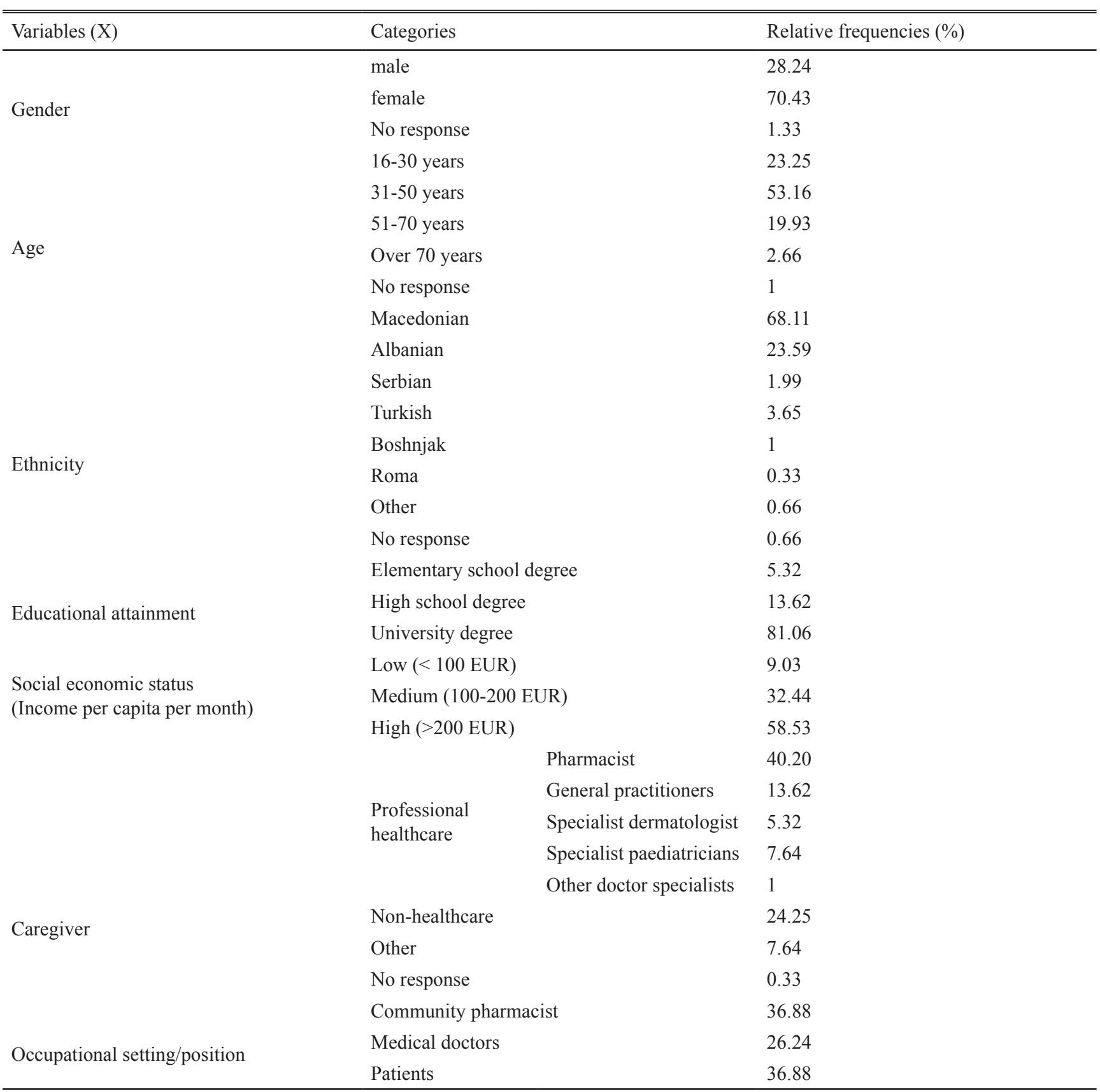


TCs treatment and further onto select the most important and significant variables that are related to TCs phobia among the respondents included in the survey, multivariate statistical analysis - partial least square (PLS), hierarchical cluster analysis (HCA), partial least square - discriminant analysis (PLS-DA) and class modelling (CM) were performed.

Thus, PLS analysis resulted with model in which $77.3 \%\left(\mathrm{R}^{2} \mathrm{Xcum}\right)$ of $\mathrm{X}$ variables explained $56.6 \%\left(\mathrm{R}^{2} \mathrm{Y}-\right.$ cum) of $\mathrm{Y}$ results with predictability of $54.4 \%\left(\mathrm{Q}^{2} \mathrm{cum}\right)$. Considering that goodness of fit $\left(\mathrm{R}^{2} \mathrm{Y}\right)$ and goodness of prediction $\left(\mathrm{Q}^{2}\right)$ should be in a reasonable agreement, preferably not separated by more than $20-30 \%$ (Malzert-Freon et al., 2010), and taking into account that $\mathrm{Q}^{2}$ is larger than 0.5 , the obtained values for $\mathrm{R}^{2} \mathrm{Y}$ and $\mathrm{Q}^{2}$ indicated that the model is interpretable. Performed ANOVA in the cross validated residuals of a $\mathrm{Y}$ variable returned $p$ value indicative of the statistical significance of the investigated model $(p<0.05)$.

Fig. 1 presents the scatter plot (map) of X observations (demographic and socio-economic characteristics of the sample; sex, age, nationality, socio-economic status, edu-
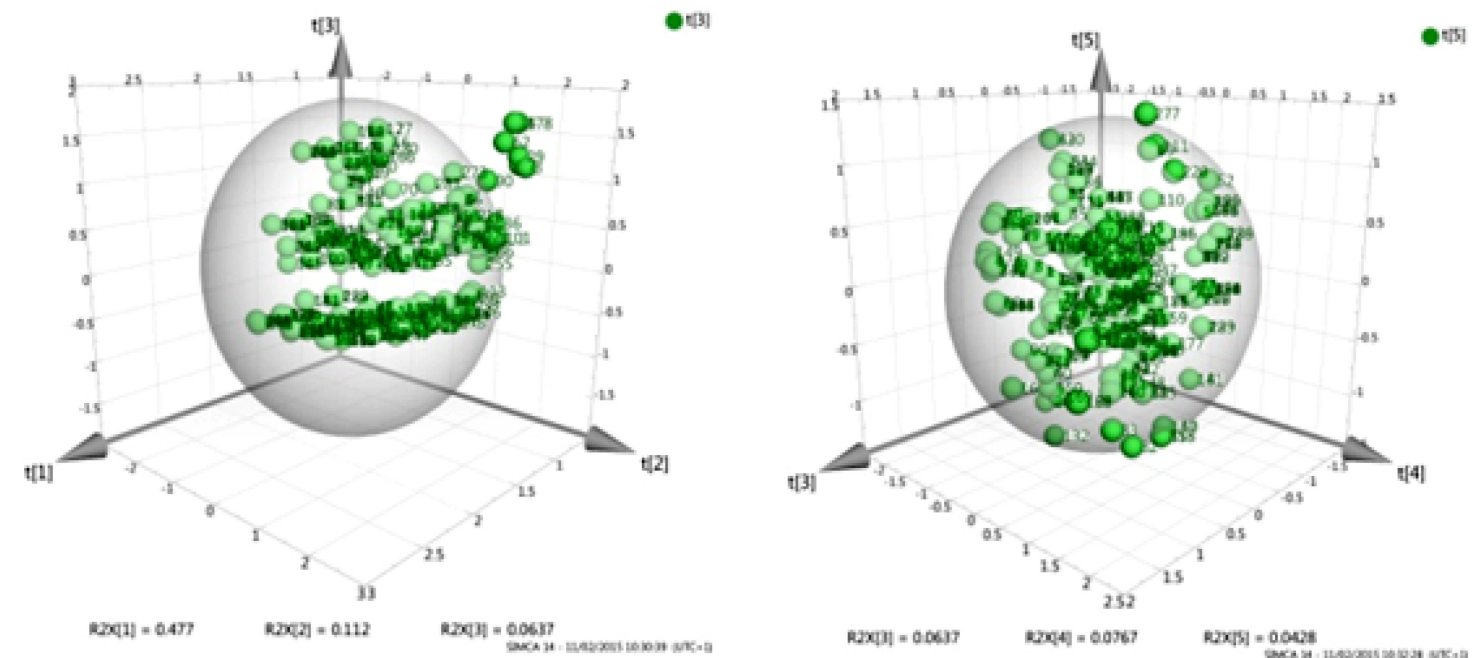

Fig. 1. PLS 3D Scatter plot representing the window of $\mathrm{X}$ space for performed analysis a) $\mathrm{X}$ - axis $\mathrm{t}[1]$, $\mathrm{Y}$-axis $\mathrm{t}[2]$ and $\mathrm{Z}$ axis $\mathrm{t}[3]$, b) $\mathrm{X}$-axis $\mathrm{t}[3]$, Y-axis $\mathrm{t}[4]$ and $\mathrm{Z}$-axis t[5].

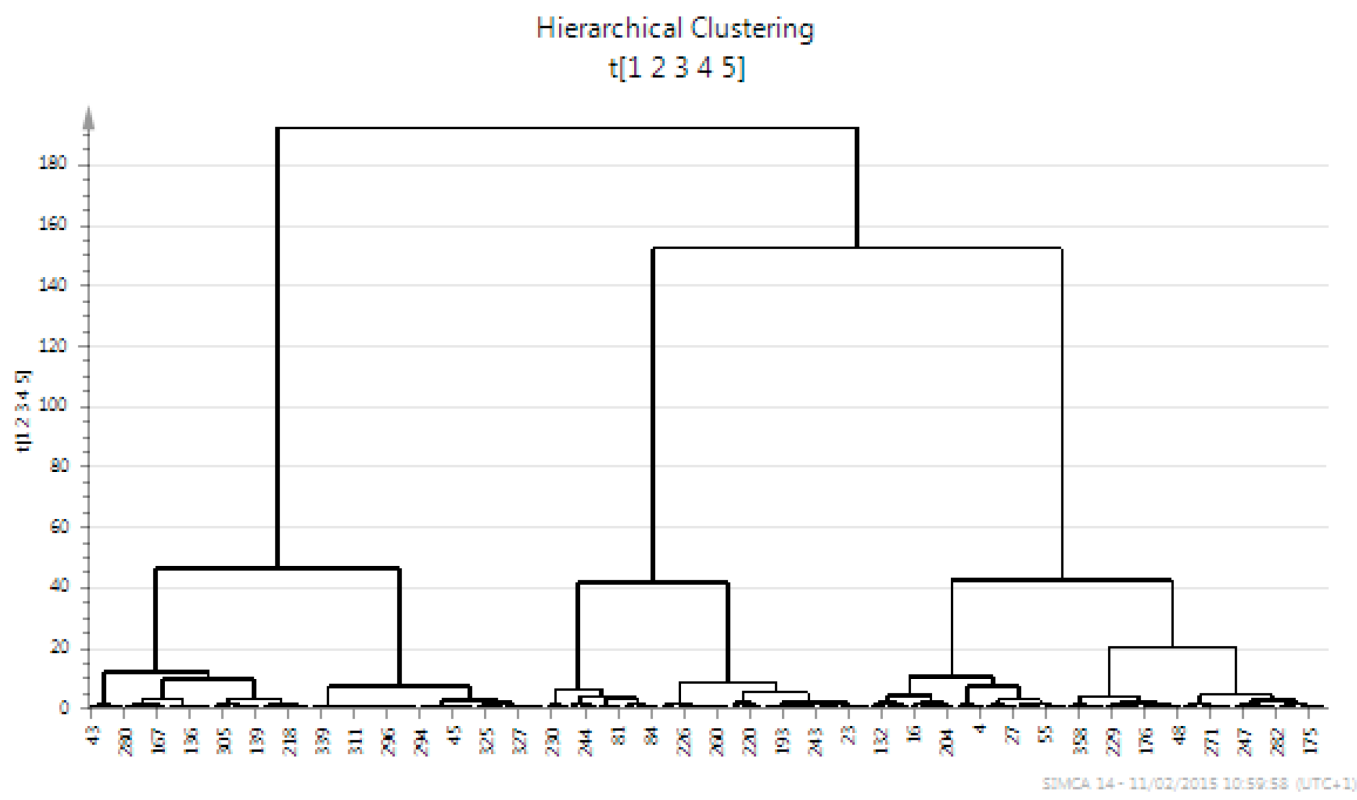

Fig. 2. Dendrogram created by Hierarchical Cluster Analysis. 
cational background, profession and the occupational setting/position from which they filled in the questionnaire (as a community pharmacist, medical doctor or patient), confirmed that the observations are well suited with respect to each other in the window of modelled X space.

Taking into consideration that relationship between variables usually might be different in different population groups, before proceeding with the in-depth analysis of the data it is very important to determine if there are any clusters or groups in the analysed population sample. With this rationale, Hierarchical Cluster Analysis (HCA) was applied (calculated with Ward's criterion and sorted by size) and dendrogram was created as follows (Fig. 2).

Analysis of the dendrogram pointed out that there were 3 main clusters (groups) in the analysed sample. To interpret the clusters seen in the dendrogram, PLS-DA was applied. PLS-DA resulted with 4-dimensional model where $\mathrm{R}^{2} \mathrm{Xcum}$ was $71.4 \%, \mathrm{R}^{2} \mathrm{Ycum}$ 96.7\% and $\mathrm{Q}^{2}$ cum 93.9\%. Score scatter plot (Fig. 3) displayed that all samples were well suited with respect to each other in the window of modelled X space without presence of outliers in the data.

The size of the regression coefficients related to scaled and centred X-variables showed that the clusters were mainly related to the profession and the position of respondents in the professional setting of completing of the questionnaire (community pharmacist, medical doctor or patient) by domination of the latest. The first cluster is related to the community pharmacist and pharmacy profession, second cluster is related to the medical doctors and accordingly to general practitioners and specialists and the third cluster is related to the patients and non-healthcare respondents.

To make further analysis of the clusters, PLS-class modelling (PLS-CM) was applied, followed by deter- mining the, relationship between variables in each cluster (group). Consequently, Table 3 displays a summary of specific PLS-CM for batch evolution model. Taking into account the present professional position at the time of assessment when key respondents filled in the questionnaire, it was noticed that $36.88 \%$ of the population surveyed were community pharmacists (PLS-Class 1), 26.24\% were medical doctors (PLS-Class 2) and 36.88\% were patients (PLSClass 3).

The survey revealed that $90.7 \%$ of interviewed respondents were familiar with TCs. Moreover, the TCs had been used by majority $(88.37 \%)$ of the responders in the past 6 months. Related to the later finding, TCs were used either personally $(48.87 \%)$, by son/daughter $(21.8 \%)$ or by other family members $(29.33 \%)$. The majority of respondents $(77.07 \%)$ used TCs rarely ( $<2$ times/year) vs $15.41 \%$ and $7.52 \%$ that used TCs often (3-4 times/year) or very often ( $>$ 5 times/year), respectively. According to the data obtained from the Ministry of Health of the RM (annual dispensing for period June 2013 - June 2014) the most commonly dispensed TCs (Table 1) were betamethasone dipropionate (cream, ointment) with 102 938, then, diflucortolone valerate (cream, ointment) with 79588 , betamethasone and salicylic acid (ointment, lotion) with 49 623, Methylprednisolone aceponate (cream, ointment) 31946 and Hydrocortisone type (cream, ointment and spray) with 253 dispensed units. It also showed that TCs were by far most commonly used for the treatment of contact $(31.2 \%)$ and atopic dermatitis $(31.45 \%)$.

Respondents were also asked for how long they had used their most recently prescribed TC. The survey revealed that $54.49 \%$ of respondents used TCs up to one week and $21.6 \%$ of them, up to 2 weeks, while the duration of treatment was not defined only by $5.98 \%$ of the sub-
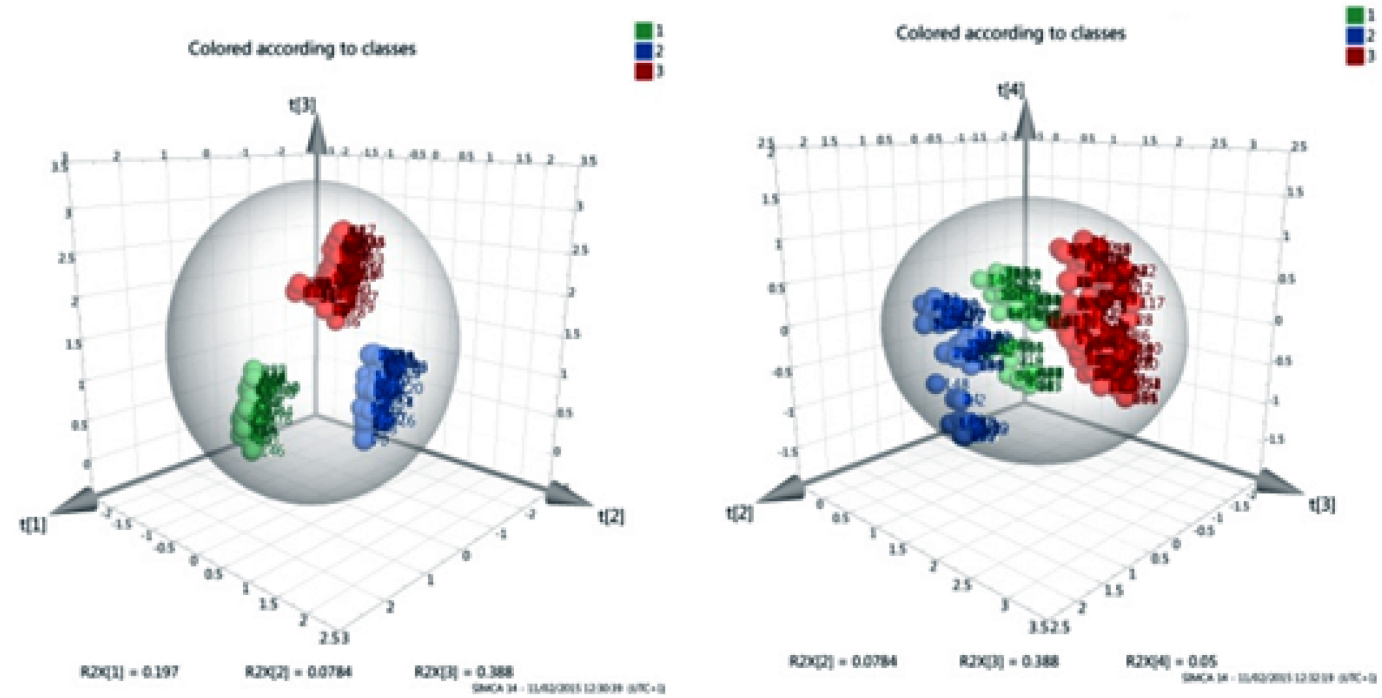

Fig. 3. PLS-DA 3D Scatter plot representing the window of $X$ space for performed analysis a) $X-$ axis $t[1]$, $Y$ - axis $t[2]$ and $\mathrm{Z}$ - axis $\mathrm{t}[3]$, b) $\mathrm{X}$-axis $\mathrm{t}[2]$, Y-axis $\mathrm{t}[3]$ and $\mathrm{Z}$ - axis $\mathrm{t}[4]$. 
Table 3. Model window of specific PLS-Class model for batch evolution model

\begin{tabular}{|c|c|c|c|c|c|c|c|c|c|}
\hline & A & $\mathrm{N}$ & Component & $\begin{array}{c}\mathrm{R}^{2} \mathrm{X}(\mathrm{cum}) \\
(\%) \\
\end{array}$ & $\begin{array}{c}\mathrm{R}^{2} \mathrm{Y}(\mathrm{cum}) \\
(\%)\end{array}$ & Limit & $\begin{array}{c}\mathrm{Q}^{2}(\mathrm{cum}) \\
(\%)\end{array}$ & Significance & Iterations \\
\hline \multirow{2}{*}{ PLS-Class (1) } & \multirow{2}{*}{2} & \multirow{2}{*}{111} & 1 & 73.5 & 54 & 0 & 53.3 & $\mathrm{R} 1$ & 3 \\
\hline & & & 2 & 81.9 & 57.1 & 0 & 55.7 & $\mathrm{R} 1$ & 6 \\
\hline \multirow{2}{*}{ PLS-Class (2) } & \multirow{2}{*}{2} & \multirow{2}{*}{79} & 1 & 64.9 & 57.1 & 0.05 & 56 & $\mathrm{R} 1$ & 3 \\
\hline & & & 2 & 74.1 & 62.8 & 0.05 & 60.8 & $\mathrm{R} 1$ & 6 \\
\hline \multirow{2}{*}{ PLS-Class (3) } & \multirow{2}{*}{2} & \multirow{2}{*}{111} & 1 & 54.1 & 51.3 & 0 & 50.2 & $\mathrm{R} 1$ & 3 \\
\hline & & & 2 & 63.5 & 54.4 & 0 & 52.5 & $\mathrm{R} 1$ & 7 \\
\hline
\end{tabular}

A - Number of model dimensions; $\mathrm{N}$ - number of observations; number of $\mathrm{X}$ variables $=7$, expanded 34; number of $\mathrm{Y}$ variables $=18$, expanded 102

jects and $5.65 \%$ were unsure about the answer. The results were in accordance with the recommendations that treatment should not be longer than two weeks on the face and 3-4 weeks on the rest of the body (www.australian prescriber.com).

For a general item exploring possible TCs phobia among population group of respondents, two main questions were evaluated, i.e. individual attitudes for TC treatment and possible fear of using them.

The question concerning the attitudes on TC treatment was answered as follows: $21.6 \%$ of all respondents had negative attitude on TC treatment, $74.75 \%$ of the respondents expressed the opposite opinion, and the other $3.65 \%$ of respondents could not give a definite answer.

Negative attitude regarding the TC use was prevalently identified among female respondents, in the age group of 31-50 years, with university degree diploma and those with high socio-economic status, as well as among the group of doctors (specialist paediatricians). Detailed analysis of specific groups' attitudes for TCs treatment is presented in Table 4.

Similar results were obtained on the question concerning the possible fear of TCs use, by individual. Actually, $63.78 \%$ of individuals use TCs without any fear, while $34.22 \%$ expressed concerns about TCs use, and 5.4\% did not give any answer. In the particular group of patients, $72.07 \%$ believed that TCs treatment was safe and used TCs without any fear and doubts, while $27.03 \%$ were concerned about the TCs use, especially females in both age groups 16-30 and 31-50 years, Macedonian nationality, with university degree and high socioeconomic status. Among health professionals groups results revealed that $58.56 \%$ of community pharmacists responded that they used TCs freely and without any fear while $37.84 \%$ were concerned about the TC use and 3.6\% did not give a definite answer. Comparable results were obtained for medical doctors where $59.49 \%$ used TCs without any fear, 39.24\% were concerned and $1.27 \%$ did not respond to this question. Being worried about TCs usage admits $73.91 \%$ of paediatricians, $31.71 \%$ of general practitioners and only $6.25 \%$ of specialists of dermatology. Obtained results were in correlation with answers to the previous question, where doctors expressed their negative attitudes and emotional aversion for TC treatment. These results were supported by the fact that most of the paediatricians $(56.52 \%)$ believed that TCs treatment was dangerous/harmful for the patients irrespective of treatment duration, $30.43 \%$ that long term treatment was dangerous and only $13.04 \%$ stated that short term TC's treatments was positive. The reason for this attitude of paediatricians is probably related to the fact that TC treatment in paediatric population should be used with extreme caution as this population group is more susceptible to TCs adverse effects, have difficulty in metabolising potent corticosteroids, and increased systematic absorption due to the skin surface area: body weight ratio (Nelson et al., 2006; Ozon et al., 2007).

It has already been shown that TCs phobias may have a negative impact on treatment adherence. It is very important to explore the origin of fears and beliefs such as fear of potential side-effects, roles of family circle and the media, lack of consistent information delivered by health-caregivers, discrepancies concerning treatment among dermatolo-

Table 4. Results regarding the attitude on TCs therapy treatment by specific group

\begin{tabular}{lcccccc}
\hline \hline Percentages (\%) & Patients & $\begin{array}{c}\text { Community } \\
\text { pharmacists }\end{array}$ & $\begin{array}{c}\text { Medical } \\
\text { doctors }\end{array}$ & $\begin{array}{c}\text { General } \\
\text { practitioners }\end{array}$ & $\begin{array}{c}\text { Specialist } \\
\text { paediatricians }\end{array}$ & $\begin{array}{c}\text { Specialist } \\
\text { dermatologists }\end{array}$ \\
\hline Positive attitude & 85.59 & 70.27 & 65.82 & 78.05 & 26.09 & 93.75 \\
Negative attitude & 13.51 & 22.52 & 31.65 & 19.51 & 73.91 & $/$ \\
No respond & 0.9 & 7.21 & 2.53 & 2.44 & $/$ & 6.25 \\
\hline
\end{tabular}

Макед. фарм. билт., 62 (1) 25 - 34 (2016) 
gists, paediatricians and general practitioners, and between medical doctors and pharmacists.

Literature data indicate that a great number of patients admitted that they have been non-adherent to TC treatment because of concerns about potential adverse events, especially skin thinning and systemic effects on growth and development (Aubert and Barbarot, 2012). In our study, only $18.6 \%$ of the total survey respondents noticed some side effects and the skin redness was the most frequently observed side-effect $(30.36 \%)$. In the particular group of patients, $18.02 \%$ of them noticed some side-effect during TC therapy, $77.48 \%$ stated that during usage they did not observe any side-effect and $4.5 \%$ did not give answer. Interestingly, $66.67 \%$ of patients who expressed fear of TC's use did not experience any side effect. Generated results highlight that negative beliefs and attitudes concerning TC treatment/use were not always based on previous negative experiences of the patients and/or observed side-effects.

Earlier studies suggested that patients were warned of the dangers of TCs by distrusted sources such as friends, relatives and media and these often unsolicited advices could lead to non-adherent to TC treatment (Smith et al., 2010).

Our survey results concerning patients knowledge and sources of information about TC treatment and proper use were as follows: $43.24 \%$ responded that they received all the information from a medical doctor, $11.71 \%$ were mostly advised by community pharmacists, $12.61 \%$ educated themselves from scientific studies, $8.11 \%$ of the patients received information from his/her friend/relative, $4.5 \%$ of the patients searched the information on the internet and $1.8 \%$ received information from the media, while $11.71 \%$ give multiple answers and $6.31 \%$ did not respond to the question. In the patients group that received information from medical doctors, males in the age group 16-30 years, of Macedonian and Albanian nationality, with elementary and high school education and low and medium socialeconomic status were determined to have statistical significance, while for those that obtained information from scientific studies statistically significant were the females, in the age group 31-50 years, of Macedonian nationality, university degree and high social-economic status.

As expected, health care professionals responded that they acquired all the information from scientific studies $(>82 \%)$.

More than $82.9 \%$ of all survey respondents confirmed that they read the patient information leaflet (PIL). However, the respondents have limited confidence in the information provided in the PIL, since only $17.12 \%$ of the patients, $27.85 \%$ of the medical doctors and $35.14 \%$ of community pharmacists confirmed that they dominantly trust PIL before TCs use. Most of the patients expressed trust to medical doctors $(66.67 \%)$, whereas doctors and community pharmacists expressed trust in their own knowledge about TCs, that is $64.56 \%$ and $38.74 \%$, respectively. Surprisingly low trust was observed among healthcare provid- ers, where $13.51 \%$ of the community pharmacists trusted medical doctors and only $1.27 \%$ vice versa.

Also, earlier studies confirmed the importance of confidence and enhanced communication among the providers, which was not observed in our study.

\section{Study constraints}

Study constraints could be looked for in the fact that no distinction was made whether TC medication was recommended for the first time or whether it had already been prescribed previously; similarly there was no information about the TCs potency class used.

\section{Conclusion}

Adherence to treatment advice is a complex issue by nature, involving many psycho-social factors. Performed analyses indicated that TCs phobia is present to some extent among surveyed population in R. Macedonia - 21.6\% and $34.22 \%$ of all respondents expressed negative attitudes and fear of TCs use, respectively. Healthcare providers expressed higher negative attitude, nearly twice and trice compared to patients' group. Notably, TCs phobia is more present among non-dermatologists than dermatologists which could be related to the fact that dermatologists have more experience, knowledge, practice and available information and hence, greater comfort using TCs agents (Nolan et al., 2012). Significant difference was observed in the specific group of paediatricians where negative attitude and fear of TCs use are present in the identical percentage of $73.91 \%$, which is most likely due to the specific population characteristics, i.e. of infants and children. Low level of negative attitude $(13.51 \%)$ and fear $(27.03 \%)$ of TCs use was observed in patients' group and these cannot be correlated with any literature data presenting higher level of TCs phobia (Charman et al., 2000). These specific findings in our study could be attributed mostly to the good quality of TCs therapy management anticipated via low level of noticed side effects and relatively high rate of patient's trust to medical doctors. However, the low level of trust was detected among patients (11.71\%) towards community pharmacists regarding the TCs use. This finding shows the need for raising the awareness of patients about community pharmacists as health care professionals responsible for medication therapy management, optimization of drug therapy and improvement of therapeutic outcomes. Considering that in this study, low mutual trust between medical doctors and community pharmacists was observed as well, inter-professional collaboration must evolve since the reasonable trust, communication, and relationship between healthcare providers are the keys for optimal medication management and improving patient compliance. 


\section{Declaration of interests}

The authors report that they have no competing interests.

\section{References}

Alston, S.J., Cohen, B.A., Braun, M., 2003. Persistent and recurrent tinea corporis in children treated with combination antifungal/ corticosteroid agents. Pediatrics 111, 201-203.

Ashcroft, D.M., Li Wan Po, A., Griffiths, C.E., 2000. Therapeutic strategies for psoriasis. J. Clin. Pharm. Ther. 25, 1-10.

Aubert, H., Barbarot, S., 2012. Non adherence and topical steroids. Ann. Dermatol. Venereol. 139, 70102-70103.

Balkrishnan, R., Camacho, F.T., Pearce, D.J., Kulkarni, A.S., Spencer, L., Fleischer, A.B., Jr., Feldman, S.R., 2005. Factors affecting prescription of ultra-high potency topical corticosteroids in skin disease: an analysis of US national practice data. J. Drugs Dermatol. 4, 699-706.

Bewley, A., 2008. Expert consensus: time for a change in the way we advise our patients to use topical corticosteroids. Br. J. Dermatol. 158, 917-920. doi: 910.1111/j.13652133.2008.08479.x. Epub 02008 Feb 08422.

Bolognia, J., Jorizzo, J.L., Schaffer, J.V., 2012. Dermatology: Sect. 19. Medical therapy 3rd ed. Elsevier/Saunders.

Charman, C.R., Morris, A.D., Williams, H.C., 2000. Topical corticosteroid phobia in patients with atopic eczema. Br. J. Dermatol. 142, 931-936.

Cornell, R.C., Stoughton, R.B., 1985. Correlation of the vasoconstriction assay and clinical activity in psoriasis. Arch. Dermatol. 121, 63-67.

Drake, L.A., Dinehart, S.M., Farmer, E.R., Goltz, R.W., Graham, G.F., Hordinsky, M.K., Lewis, C.W., Pariser, D.M., Webster, S.B., Whitaker, D.C., Butler, B., Lowery, B.J., Raimer, S.A., Krafchik, B.R., Olsen, E., Weston, W.L., 1996. Guidelines of care for the use of topical glucocorticosteroids. American Academy of Dermatology. J. Am. Acad. Dermatol. 35, 615619.

Ference, J.D., Last, A.R., 2009. Choosing topical corticosteroids. Am. Fam. Physician. 79, 135-140.

Haber, R.M., 2010. Topical management of recalcitrant psoriasis \& eczema. Clinical Evidence 6.

Haeck, I.M., Hamdy, N.A.T., Timmer-de Mik, L., Lentjes, E.G.W.M., Verhaar, H.J.J., Knol, M.J., De Bruin-Weller, M.S., Bruijnzeel-Koomen, C.A.F.M., 2009. Low bone mineral density in adult patients with moderate to severe atopic dermatitis. Brit. J. Dermatol. 161, 1248-1254.

Hengge, U.R., Ruzicka, T., Schwartz, R.A., Cork, M.J., 2006. Adverse effects of topical glucocorticosteroids. J. Am. Acad. Dermatol. 54, 1-15; quiz 16-18.

Jacob, S.E., Steele, T., 2006. Corticosteroid classes: a quick reference guide including patch test substances and crossreactivity. J. Am. Acad. Dermatol. 54, 723-727.

Kanfer, I., 2010. Strategies for the bioequivalence assessment of topical dermatological dosage forms. J. Bioequiv. Availab. 2(5): 102-110. doi: 10.4172/jbb. 1000040.

Katz, H.I., Hien, N.T., Prawer, S.E., Mastbaum, L.I., Mooney, J.J., Samson, C.R., 1987. Superpotent topical steroid treatment of psoriasis vulgaris--clinical efficacy and adrenal function. J. Am. Acad. Dermatol. 16, 804-811.
Lee, M., Marks, R., 1998. The role of corticosteroids in dermatology. Australian Prescriber 21, 9-11.

Leung, A.C., Barber, K., 2003. Managing childhood atopic dermatitis. Adv. Therapy 20, 129-137.

Malzert-Freon, A., Hennequin, D., Rault, S., 2010. Partial least squares analysis and mixture design for the study of the influence of composition variables on lipidic nanoparticle characteristics. J. Pharm. Sci. 99, 4603-4615. doi: 4610.1002/ jps.22177.

Mason, J., Mason, A.R., Cork, M.J., 2002. Topical preparations for the treatment of psoriasis: a systematic review. Br. J. Dermatol. 146, 351-364.

Menter, A., Gottlieb, A., Feldman, S.R., Van Voorhees, A.S., Leonardi, C.L., Gordon, K.B., Lebwohl, M., Koo, J.Y., Elmets, C.A., Korman, N.J., Beutner, K.R., Bhushan, R., 2008. Guidelines of care for the management of psoriasis and psoriatic arthritis: Section 1. Overview of psoriasis and guidelines of care for the treatment of psoriasis with biologics. J. Am. Acad. Dermatol. 58, 826-850. doi: 810.1016/j.jaad.2008.1002.1039.

Menter, A., Korman, N.J., Elmets, C.A., Feldman, S.R., Gelfand, J.M., Gordon, K.B., Gottlieb, A.B., Koo, J.Y., Lebwohl, M., Lim, H.W., 2009. Guidelines of care for the management of psoriasis and psoriatic arthritis: section 4. Guidelines of care for the management and treatment of psoriasis with traditional systemic agents. J. Am. Acad. Dermatol. 61, 451485.

Miller, J.A., Munro, D.D., 1980. Topical corticosteroids: clinical pharmacology and therapeutic use. Drugs 19, 119-134.

National Guideline, C., 2011. Management of atopic eczema in primary care. A national clinical guideline. Agency for Healthcare Research and Quality (AHRQ), Rockville MD.

Nelson, A.A., Miller, A.D., Fleischer, A.B., Balkrishnan, R., Feldman, S.R., 2006. How much of a topical agent should be prescribed for children of different sizes? J. Dermatolog. Treat. 17, 224-228.

Nolan, B.V., Levender, M.M., Davis, S.A., Feneran, A.N., Jr, A.B.F., Feldman, S.R., 2012. Trends in the use of topical over the counter products in the management of dermatologic disease in the United States. Dermatology Online Journal 18.

Ozon, A., Cetinkaya, S., Alikasifoglu, A., Gonc, E.N., Sen, Y., Kandemir, N., 2007. Inappropriate use of potent topical glucocorticoids in infants. J. Pediatr. Endocrinol. Metab. 20, 219-225.

Pariser, D.M., 1991. Topical steroids: a guide for use in the elderly patient. Geriatrics 46, 51-54, 57-60, 63 .

Renaud-Vilmer, C., Cavelier-Balloy, B., Porcher, R., Dubertret, L., 2004. Vulvar lichen sclerosus: effect of long-term topical application of a potent steroid on the course of the disease. Arch. Dermatol. 140, 709-712.

Roos, T.C., Geuer, S., Roos, S., Brost, H., 2004. Recent advances in treatment strategies for atopic dermatitis. Drugs 64, 26392666.

Saeki, H., Furue, M., Furukawa, F., Hide, M., Ohtsuki, M., Katayama, I., Sasaki, R., Suto, H., Takehara, K., 2009. Guidelines for management of atopic dermatitis. J. Dermatol. 36, 563-577.

Smith, S.D., Hong, E., Fearns, S., Blaszczynski, A., Fischer, G., 2010. Corticosteroid phobia and other confounders in the treatment of childhood atopic dermatitis explored using parent focus groups. Australas. J. Dermatol. 51, 168-174. 
Smith, S.D., Stephens, A.M., Werren, J.C., Fischer, G.O., 2013 a. Treatment failure in atopic dermatitis as a result of parental health belief. Med. J. Aust. 199, 467-469.

Smith, S.D., Stephens, A.M., Werren, J.C., Fischer, G.O., 2013 b. Treatment failure in atopic dermatitis as a result of parental health belief. Med. J. Aust. 199, 467-469.
Tadicherla, S., Ross, K., Shenefelt, P.D., Fenske, N.A., 2009. Topical corticosteroids in dermatology. J. Drugs Dermatol. 8, 1093-1105.

Torres, M.J., Canto, G., 2010. Hypersensitivity reactions to corticosteroids. Current Opinion in Allergy and Clinical Immunology 10, 273-279.

\title{
Резиме
}

\section{Проценка на ставовите на пациентите, лекарите и фармацевтите во Р. Македонија за употребата на локалните кортикостероиди}

\author{
Марија Главаш-Додов ${ }^{1 *}$, Маја Симоноска-Црцаревска ${ }^{1}$, Вања Шулевски $^{1}$, \\ Рената Славеска-Раички ${ }^{1}$, Агрон Старова ${ }^{2}$

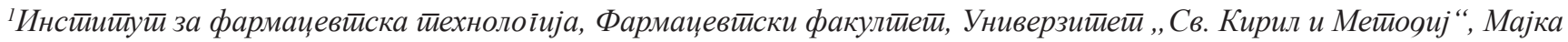 \\ Тереза 47, 1000 Скойје, Макеоонија \\ ${ }^{2}$ Универзииетеиска клиника за яермайолоіија, Мајка Тереза 47, 1000 Скойје, Макеяонија
}

Клучни зборови: локални кортикостероиди, кортикофобија, истражување

И покрај тоа што терапијата со локални кортикостероиди е златен стадард во третманот на голем број на дерматолошки состојби, стравот поврзан со нивната употреба е феномен присутен меѓу пациентите и здравствените работници. Ставот на здравствените работници во однос на примената на кортикостероидите може да има значајно влијание врз појавата на кортикофобија кај пацинетите. Од тие причини, неопходно е да се обрне внимание на оваа појава со оглед дека истата може да има значително влијание врз прифаќањето и придржувањето кон терапијата од страна на пациентите.

Имајќи во предвид дека вакво истражување досега не е направено во Р. Македонија (РМ), структуриран беше анонимен прашалник со цел да се согледаат ставовите и обемот на изразеност на предрасудите кон употребата на локалните кортикостероиди кај пациентите и здравствените работници, а во насока истите да се објаснат, односно да се истражат причините и да се дефинираат идните насоки за обука на здравствените професионалци во ова поле.

Добиените резултати од истражувањето укажаа дека кортикофобијата е присутна кај испитуваната популација (21,6\% и $34,22 \%$ од сите испитаници имаа негативен став или страв, соодветно кон употребата на локалните кортикостероиди). Приближно $27 \%$ од пациентите се изјасниле дека се плашат да ги употребуваат овие лекови. Негативниот став кон употребата на локалните кортикостероиди е повеќе изразен кај здравствените работници ( $39 \%)$, при што обемот на изразеност на предрасудите е доминантен кај специјалистите педијатри (73,91\%).

Севкупните резултати би можеле да претставуваат основа за идентификација и менаџирање на кортикофобијата со цел подобра соработка со пациентите и ефикасен третман. 